\title{
取手市高須地区の多主体連携と地域運営からみた都市近郊農村の公共空間マネジメント \\ Public Space Management in the Suburban Rural Areas Viewed from the Cooperation of Multiple Agents and Community Management, in Takasu District of Toride City
}

\author{
湯淺 かさね* 池邊このみ*
}

Kasane YUASA Konomi IKEBE

\begin{abstract}
The purpose of this paper is to clarify the activities of multiple subjects based on public facilities in the suburban rural areas, the characteristics and problems of community management, the actual condition of the space in which they are deployed, and the way public spaces are managed. The subject of the research is the Takasu district of the Toride. As research methods, we conducted literature/document surveys, field surveys, and interviews with facility managers and stakeholders. Based on the results, we made the following three recommendations: 1) Give the public space a function that will be able to connect the history of the area and the relationship with the living industry and set it as the base of the area. 2) Act to encourage residents' understanding that private premises and facilities can also be public spaces. 3) Participate roles between local residents and local organizations and the administration.
\end{abstract}

Keywords: public facility, exterior space, facility management (FM), effective use, Toride Art Project キーワード：公共施設，屋外空間，ファシリティマネジメント（FM）, 活用，取手アートプロジェクト

\section{1. はじめに}

\section{(1) 背景と目的}

現在，人口減少や高齢化が進む中，公共空間の在り方を通して 地域社会の今後を住民と自治体が共に主体的に考えることが重要 となっている。特に民間の施設が少ない農村等の地域においては, 公共施設の在り方が住民の活動に大きな影響を与えると考えられ, 住民の価值観を反映させた公共施設マネジメントが求められてい る 1)。また, 屋外の公共空間マネジメントに関しては, 近年地域 の持続性にとって重要である 2)3) と指摘されると共に社会実験等 の取組みが展開されているが，中心市街地以外では公共空間をマ ネジメントの対象として積極的に地域の活動の場として活用する 取組みは，必ずしも十分に行われていない。加えて，地域活動の 実情においては住民のつながりの希薄化により地域コミュニティ の衰退が指摘され，その維持が課題となっている4)。

そこで本稿では，人口減少，少子高齢化，公共施設の廃止・活 用等，現代日本における一般的な諸課題を抱えた都市近郊農村で ある取手市高須地区を対象とし，地域の空間やコミュニティの特 徵を活かした取組みの実態を明らかにしていく。屋内外の公共空 間を拠点とした多主体の活動と地域運営の特徵, 及びそれらが展 開されている空間の構成や使われ方を明らかにし，公共空間のマ ネジメントの在り方の考察を通し，地域がその特徴を活かして存 続していくための示唆を得ることを目的とする。

本稿では，自治体が所有・管理する建物としての公共施設に加 え，公的な機能や役割を持つ民間施設も扱うため，これらを合わ せて「公共的施設」と記載する。「公共空間」については既往の文 献5)6を参考に,「土地の所有に関わらず, 不特定の人に公開され, 営利を主目的としない活動が行われている公的な性質を持つ施設 や空間」とする。よって単に建物を示す場合は「公共的施設」, 空 間の機能や活動の場を示す場合には「公共空間」の語を使用する。

\section{（2）対象の概要と方法}

取手市高須地区は，取手市と合併した旧藤代町のエリアにあり
地区全体が市街化調整区域である。高須地区は大字押切・神浦・ 大留の 3 区と大字高須の本田・長田・下の 3 区を合わせた 6 区か ら成る。土地利用としては, 利根川の支流である小貝川の堤防沿 いを中心に住宅が並ぶ以外はほぼ全域に田圃が広がり, 明治時代 から大きな変化は無い7)。高須地区の西側に隣接する桜が丘地区 では 1990 年代にかけて宅地開発が行われ，分譲住宅が立ち並ぶ 市街化区域となっており，人口流入により 1993 年には新しく桜 が丘小学校が開校した。その後 2005 年には高須地区の小学校が 桜が丘小学校と統合される形で閉校となっている。高須小学校や 公民館等複数の公共的施設（表一1）とそれらの立地する一帯の 公共空間 (以下，「高須公民館一帯」と記載）を拠点として, 住民 が 3 つの新たな主体（表一2）と共に主体的に地域運営を行って きた点に着目する。

まず高須公民館一帯の空間と出来事の変遷を整理する (第 2 章)。 次に, 関連する多主体の活動の実態と連携, それらが地域運営に もたらした変化について明らかにする (第 3,4,5 章)。最後に, 調 查で得た知見に基づき都市近郊農村における公共空間のマネジメ ントの在り方を考察する (第 6 章)。方法としては文献・資料調

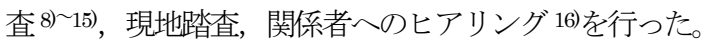

\section{表-1＼cjkstart対象地周辺図と対象とする主体の概要}

\begin{tabular}{|c|c|c|c|c|}
\hline 対象地周辺图 & 主体名 & 活動場所 & 活動主体 & 高須地区での活動時期 \\
\hline \multirow{2}{*}{\begin{tabular}{|l|} 
高須公民館一帯 \\
\end{tabular}} & 高須小学校 & 高淇小学校 & $\begin{array}{l}\text { 児童生徒、 } \\
\text { 教職員、PTA }\end{array}$ & $\begin{array}{l}\text { 1882(開校) } \\
\sim 2005 \text { 年(閉校) }\end{array}$ \\
\hline & 高須幼稚園 & 高須糼稚園 & $\begin{array}{l}\text { 園児、教職員、 } \\
\text { PTAA }\end{array}$ & $\begin{array}{l}\text { 1955(開園) } \\
\sim 2005 \text { 年(閉園) }\end{array}$ \\
\hline & 農協 & 農協高須支所 & $\begin{array}{l}\text { 廧協職員、 } \\
\text { 地元屡家 }\end{array}$ & $\begin{array}{l}\text { 1960㑯(支所設置) } \\
\text { ２005年(閉錤) }\end{array}$ \\
\hline & 高須公民館 & $\begin{array}{l}\text { 高須公民館 } \\
(\text { 元須農村莱落 } \\
\text { センタ }\end{array}$ & $\begin{array}{l}\text { 公民館運営 } \\
\text { 委買会、利用 } \\
\text { 者、貿童 }\end{array}$ & $\begin{array}{l}\text { 1979年(高須分館を建替 } \\
\text { 新築)～現在 }\end{array}$ \\
\hline & 社会福祉法人 & 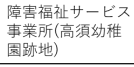 & $\begin{array}{l}\text { 利用者、職員、 } \\
\text { 地元住民ボ } \\
\text { ンテテア }\end{array}$ & $\begin{array}{l}\text { 1999年(旧幼稚園舎に事 } \\
\text { 業所移転)垷在 }\end{array}$ \\
\hline & $\begin{array}{l}\text { 環境系 } \\
\text { NPO法人 }\end{array}$ & $\begin{array}{l}\text { 旧高須小学校 } \\
\text { 特教教空棟 }\end{array}$ & NPO職員 & 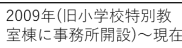 \\
\hline$\stackrel{N}{1}$ & $\begin{array}{l}\text { 取手アート } \\
\text { ア゚ジェクト } \\
\text { (TAP) }\end{array}$ & $\begin{array}{l}\text { 高須ハウス } \\
\text { (旧農協事務棟) }\end{array}$ & $\begin{array}{l}\text { TAP事務局、 } \\
\text { アー } \\
\text { 地元住民 }\end{array}$ & 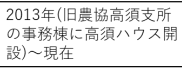 \\
\hline
\end{tabular}

*千葉大学大学院 園芸学研究科 
表一2 高須地区で活動する新たな主体の概要

\begin{tabular}{|c|c|c|c|c|c|}
\hline 主体 & 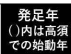 & 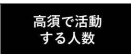 & 活碃目的 & 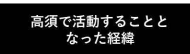 & 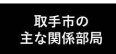 \\
\hline & $\begin{array}{l}\text { 1997年) } \\
(1999 \text { 年) }\end{array}$ & 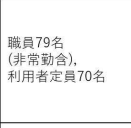 & 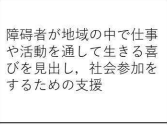 & 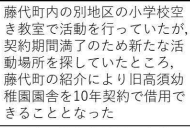 & 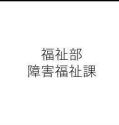 \\
\hline & $\begin{array}{l}2008 \text { 年 } \\
\text { (2011年) }\end{array}$ & 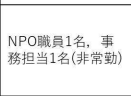 & 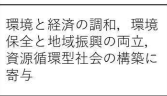 & 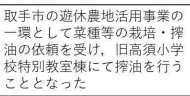 & 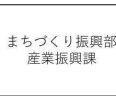 \\
\hline & $\begin{array}{l}\text { 1999年) } \\
\text { (2005年) }\end{array}$ & 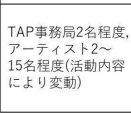 & 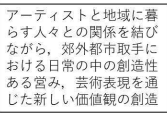 & 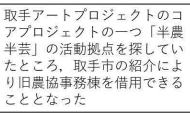 & 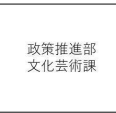 \\
\hline
\end{tabular}

\section{(3) 既往研究}

本稿に関連する研究として, 地域の公共施設の位置づけの変化, 地域公共施設の管理運営，住民主体による地域運営，公共空間の マネジメント等がある。地域公共施設とりわけ公民館の位置づけ の変化については，施設の再編を見据えた公民館機能の多様性 ${ }^{17)}$, 公民館のまちづくり拠点化に関する研究 18)がある。地域公共施設 の管理運営については，指定管理者制度に関寸る研究が多い他， 学校と地域まちづくり組織の連携による学校施設の管理運営 ${ }^{19)}$ に関する研究がある。また，地域運営に関しては農村部における NPO の活動の展開と住民参加に関する研究 20)がある。公共空間 のマネジメントについては，主に中心市街地の道路 21)，公園 22) 等の多主体の連携に関する研究が行われている。これらに対し， 本稿は多主体の活動や住民主体による公共施設の管理運営に関し て地域の変遷加読夕解く点, 空間的な視点も併せて把握寸る点 において既往の研究を発展させる独自性を有すると共に，都市近 郊農村における公共空間のマネジメントの方向性について知見を 加える点においても意義を持つものとして位置付けられる。

\section{2. 高須地区の公共空間と出来事の変遷及び特徵}

\section{（1）公共空間の変遷と現代につながる特徴}

高須公民館一帯の変遷を表-3 に示す。郝完に隣接して高須村 役場や高須小学校が構えられた一帯の敷地が，時代を経て拡張・ 分割され様々な用途の公共的施設用地となってきたことが分かる。 高須地区は古くからの農村地帯であり，何事にも隣近所が助け合 う暮らしが営まれてきた。住民同士の顔はだいたい覚えており，

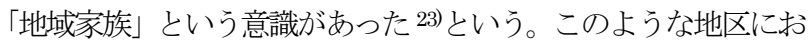
いて中心となっていた高須公民館では「農村社会教育」や「青年 教養講座」が行われた ${ }^{24)}$ 。小学校と公民館の間の敷地に農協の支 所も構えられ，高須公民館一帯は農と教育の接点としての公共空 間であったといえる。2005 年に閉校となった高須小学校校舎は既 に解体され，農協支所も同時期に閉鎖となったが, 2013 年からは 取手アートプロジェクト 25)（以下，TAP と記載）の一環として行 われている「半農半芸」の拠点である TAKASU HOUSE (以下, 高須八ウスと記載）が旧農協事務所棟に構えられたことで，現在 再び地域の農と社会教育をつなぐ場として機能し始めている。

\section{（2）出来事の変遷の整理}

高須地区の出来事及び関連する事業の変遷について表一4に整

\section{表一3＼cjkstart高須公民館一帯における公共空間の変遷}

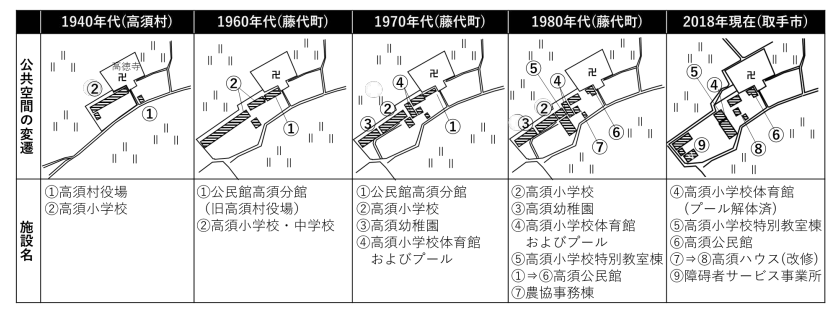

理した。大きくは, 高須小学校の生徒が増え PTA が発足する等, 小学校を中心に地区運営が行われていた第 I 期, 高須村を含む 1 町 4 村が藤代町に編入され，高須公民館の新築で地域活動がより 活発化した時期から，藤代町と取手市の合併に伴い小学校が閉校 となるまでの第I期，小学校・幼稚園の閉校・閉園により高須公 民館一帯の活動が大きく変化した第而期，新たな主体 TAP が高 須に入ってから現在までの第IV期に分けられる。この時代区分に 合わせ，公民館一帯の公共空間の活動を，図-1・2 に整理した。 第I期に各種行事が高須公民館一帯で活発に行われるようになっ た後，第期には公共空間での活動の種類が減少し，屋内での活 動が主となった。第IV期には活動主体・活動空間共に多様化し, 高須八ウスの屋外空間でのブルーベリー等の栽培や社会福祉法人 が手芸サロン等に施設を開放していることが確認された。

\section{3. 高須小学校を拠点とした地域運営（第 I 期〜第 II 期）}

本項では，主に高須小学校を拠点として育まれた地域の活動と 運営の様子に着目し，第 I 期以前の小学校開校から閉校となる第 II期の終わりまでの変遷について整理する。

\section{（1）第 I 期 : 地域の拠点の小学校〜PTA 黎明期}

高須小学校は 1882 年に開校式が行われて以降，高須公民館一 帯の中でも地域コミュニティの拠点として存在してきた。1910 年の新校舎建設の際は住民が各戸から木を持ち寄り敷地内に植え たという 26)。1948年，終戦後の混乱の中高須小学校 PTA が発足 し，1954 年には活発な活動が高須村教育委員会から表彰された。

\section{（2）第 II 期：PTA 活動全盛期～創立 100 周年～閉校}

1955 年, 高須村の藤代町への編入と共に藤代町立高須小学校と なった。PTA 活動は更に活発化し，1958 年には業績が極めて顕 著であるとして日本 PTA 全国協議会と文部大臣からの表象を受 けている。小学生のいない家庭も賛助会員としてPTAに加入し， 地区毎の PTA 組織も生まれ, 高須地区全体で熱心な活動が営ま れた 28)。1973 年，高須小学校の校庭に藤代町で最初の公立幼稚 園として, 高須幼稚園が併設された。開園前は高須小学校 PTA 設置就学前教育の場として隣接する郝完や小学校校舎を使用して 運営され，運営費は全て廃品回収で賄ったという27。

1982 年には小学校創立 100 周年記念事業が行われた。事業費 358 万円のうち行政の補助金は 20 万円のみであり, 殆どが地区

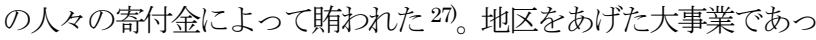
たことが窺える。その後，2005 年の藤代町と取手市の合併と同 年に小学校・幼稚園共に閉校・閉園となった。

\section{4. 高須公民館の整備に伴う地域活動の拡大と地域住民による 施設運営（第 II 期〜第IV 期）}

本項では高須公民館が新築され地域活動が活発化した第I期以 降について整理していく。

\section{（1）第I期 : 高須公民館の整備による新たな地域の拠点化}

高須地区の公民館は，小学校に隣接していた旧高須村役場の建 物を高須分館として使っていた ${ }^{29}$ 頃に始まる。取手市の公民館に つては主に中学校区毎に配置され，一般的な市直営の運営形態 であることに対し，旧藤代町エリアの公民館については藤代町に なる以前の旧町村単位に配置されたものが現在も維持されている。

旧藤代町の公民館は本館・分館制となっており，分館は地域住 民による運営が行われてきたという特徵がある。現在の高須公民 館は高須分館を建て替えるかたちで, 1954 年に「高須コミュニテ イ農村集落センター」として竣工した。当初から現在の公民館と 同様に地域住民の交流・地域活動の拠点としての位置づけであっ たが，農村集落センター建設のための旧自治省の補助金活用によ つて建設された 28) 31) 32)。かつては地域の冠婚葬祭の会場, 地域の こども文庫としても使用されていた ${ }^{30}$ 。 
表-4 高須地区に関連する出来事の変遷

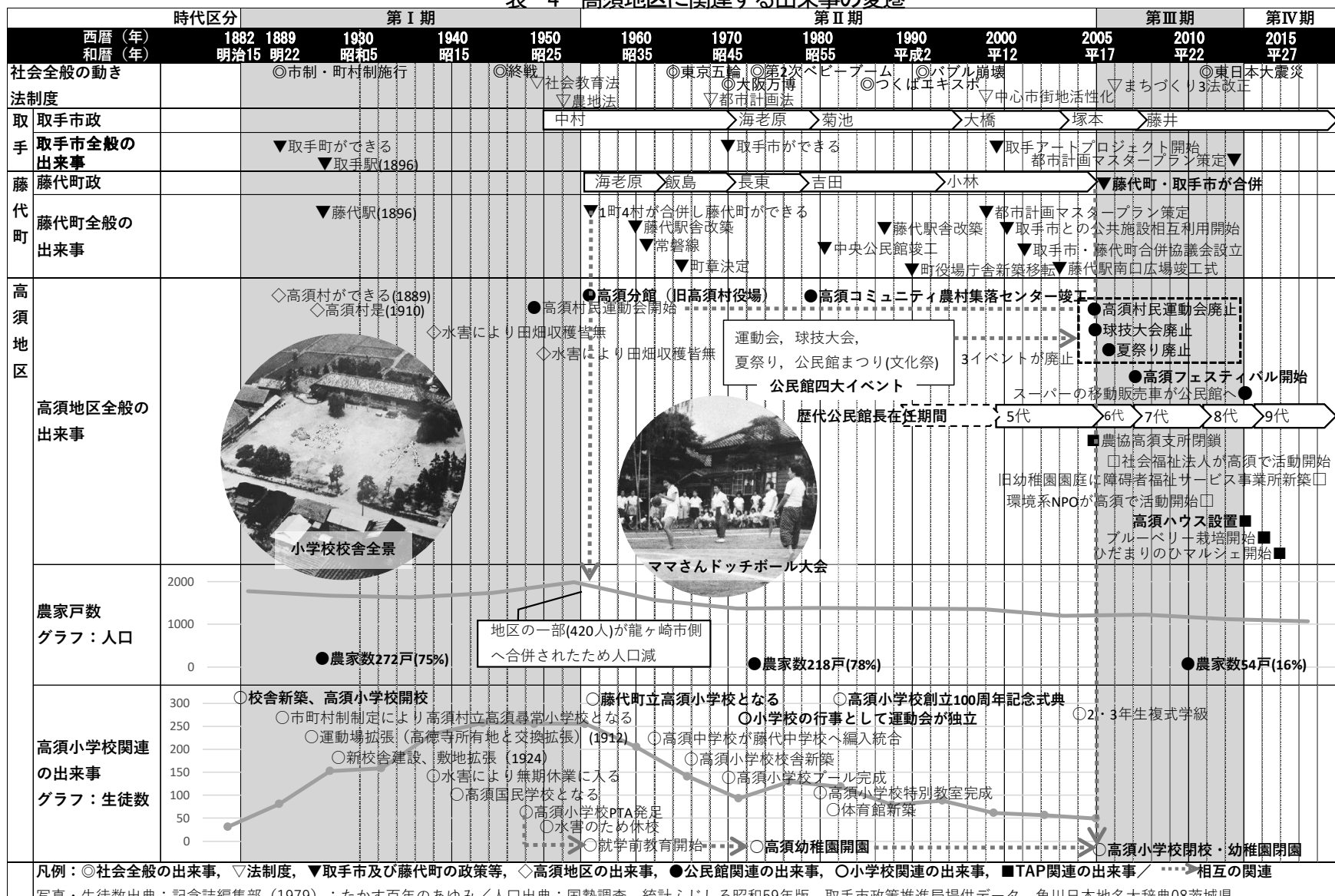

写真・生徒数出典：記念誌編集部（1979）：たかす百年のあゆみ/人口出典：国勢調査，統計ふじしろ昭和59年版，取手市政策推進局提供データ，角川日本地名大辞典08茨城県

《活動内容》《活動時期と活動場所》《活動主体》

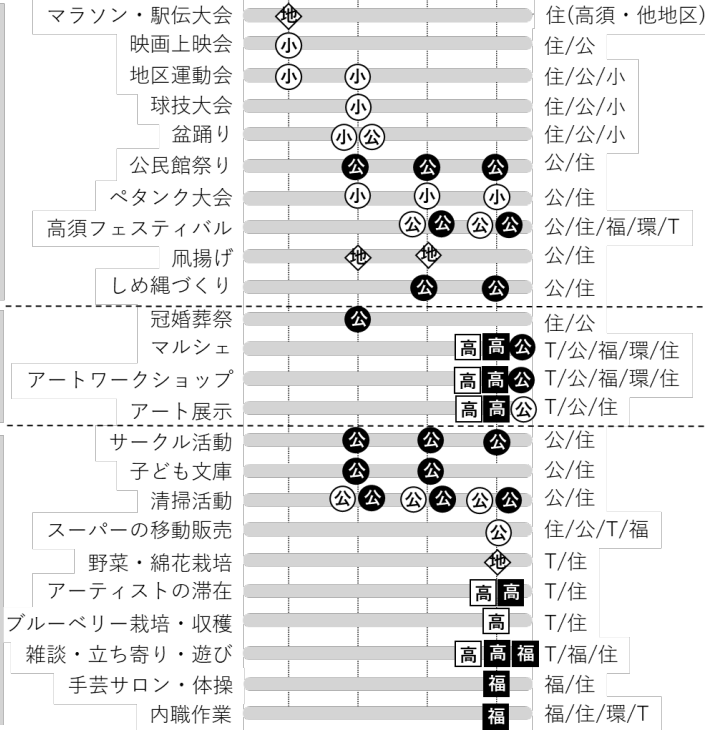

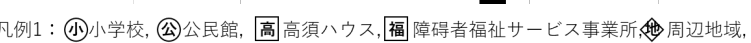
※記号の色 白地黑文字: 屋外, 黒地白文字: 屋内

凡例 2 : 住(住民)/公(公民館)/小(小学校)/T(TAP)/福社会福祕法人)/環(環境采NPO)

図-1 高須公民館一帯と周辺地域の活動の変遷

（2）第亚 IV期 : 住民主体の公民館運営と近年の変化

1）地元住民による館長と公民館運営委員会

取手市との合併後も旧藤代町エリアでは藤代公民館が中央公民 館の役割を担っている。藤代公民館には，市の職員が公民館担当 者として配置され各公民館との連絡調整を行う。各公民館の館長 は市から委嘱を受ける形で地域住民から選出されているが，新住 民の増えた地区では地元に館長の担い手がおらず，市の職員が館
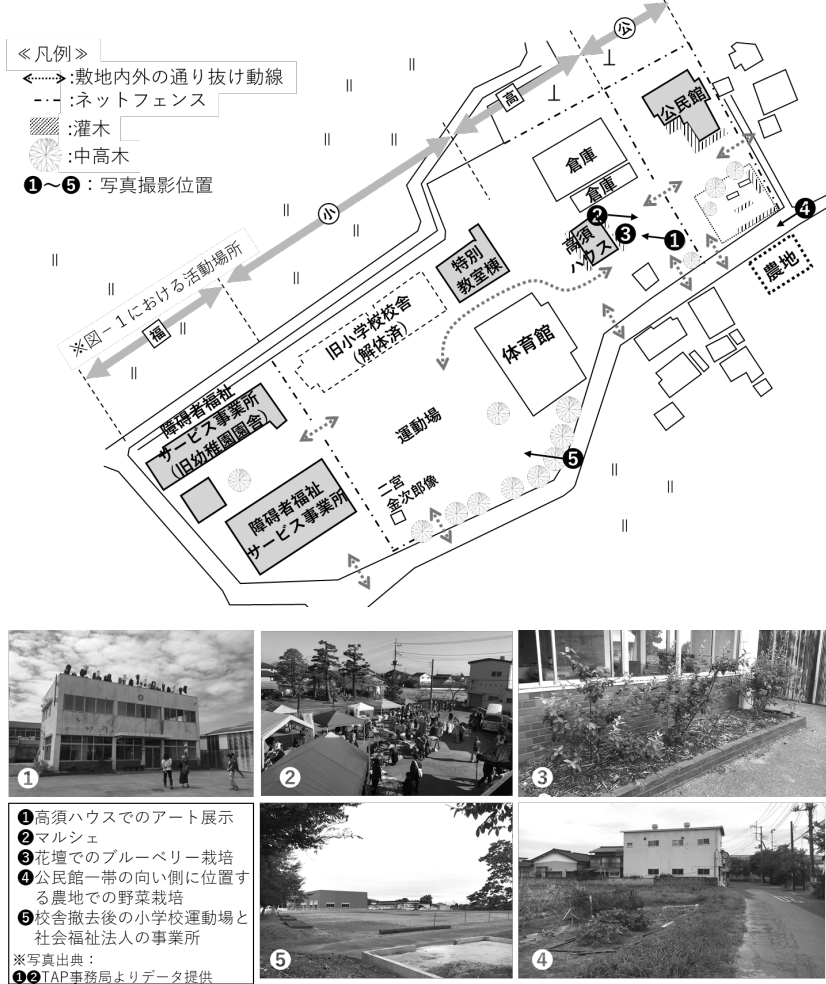

図－2＼cjkstart第IV期における高須公民館一帯の空間の様子

長となった事例も出ている ${ }^{30)}$ 。高須公民館については現在 9 代目 の館長がおり，他に市の非常勤職員一般職として雇用される 3 名 の地元住民が交代で勤務している。公民館の運営については高須 地区内の 6 区の区長による区長会, 公民館で活動する団体代表者, 
PTA 等の地域住民と公民館館長及び非常勤職員らで構成される 高須公民館運営委員会が組織されている。高須小学校が閉校とな る以前は小学校の校長等の教員も名を連ね, 2007 年までは委員の 数は 40 名以上, 2018 年度は 28 名の委員がいる ${ }^{14)}$ 。公民館運営 委員会では, 毎年 7 つ程度の公民館事業の日程・概要の企画が行 われ，各事業の詳細企画及び実施を委員がグループに分かれて担 っている。高須地区は他公民館と比較すると規模が小さく地域住 民も少ないが，独自性のある事業を毎年継続して行っている 32 。

高須公民館の運営のうち，草刚りや屋外の清掃については毎月 1 回のペースで区長会が持ち回りで行い，屋内の清掃については 館長及び非常勤職員にて行われている。公民館の維持管理活動が 住民主体で行われているのは，旧藤代町エリアでも現在は高須公 民館のみである。地域の中にはこのように住民が公民館に関わり 続けないと，高須公民館が廃止されてしまうのではという危機感 を持つ者もいるという 31）。実際，高須公民館を拠点として活動し ている団体は現在 5 団体, 他地区の団体の活動も受け入れている が，稼働率は約 $12 \%$ と市内公民館で最も低い 34)現状がある。

2）イベント・年中行事を通した多様な主体との連携

高須公民館一帯では小学校と公民館を中心として様々なイベン ト・年中行事が行われてきた。かつて藤代町エリアにおける公民 館では「四大イベント」と呼ばれるものがあり, 春の球技大会, 盆踊り，秋の運動会，早春の文化祭（公民館祭り）がそれに当た る。しかし, 現在は文化祭以外のイベントは既に廃止されている。

一方, 盆踊りが廃止されたことで 2007 年から始まったのが「高 須フェスティバル」であり，毎年 100～200 名もの地域住民が集 まる。お盆の時期, 夕方から夜にかけて行われた盆踊りと異なり, 学校が夏休多に入った後の最初の日曜日の昼間に開催されるイ心゙ ントであり，主に地域の子供たちの参加を促すような出店やゲー ム・流しそうめんなどが行われている。特に流しそうめんについ ては高須フェスティバルの開始当初から 10 年以上継続して行わ れており，楽しみにしている住民が多いという。流しそうめんに 使用する竹については，地域住民の所有する竹林にて区長会を中 心としたメンバーが伐採し，運搬し，組み立てて行われる。

3）公民館運営費に関する行政と地域の役割分担

各種イベントが廃止となったのは, 参加者の減少等で運営側住 民の負担が大きかったことに加え，取手市との合併により藤代町 当時と比べて公民館運営に関する予算が大幅に削減され，継続が 困難になったことが要因であるという30)。現在，イベントに係る 費用のうち一部謝礼金や賞品・消耗品購入については市で予算計 上されている。一方，食糧費等の予算計上されない費用や市の予 算の不足分については，イベント参加費や住民からの寄付・ご祝 儀等を公民館運営委員会が管理し費用に充てている。なお，平常 時の公民館運営に係る費用は全て市の予算にて賄われている。

\section{5. 新たな主体との関係構築に伴う地域運営の変化（第IV期）}

高須公民館一帯では現在, 社会福祉法人, 環境系 NPO 法人, TAP 等, 新たな主体の活動が行われ始めている。中でも, 2013 年から高須地区に拠点を構えたTAP が地元住民と他の新たな主 体との間を繋ぐ役割も担っているため，本項では第IV期における TAP と他の新たな主体や地域との関係構築に伴うプロセスや地 域運営の変化を整理する。

\section{（1）高須ハウス整備のプロセスと地域の反応}

高須八ウスは TAP のコア・プロジェクト「半農半芸」の拠点 である。2011 年のプロジェクト開始時においては取手市内の別の 地域で活動していた。2013 年度に新たな拠点を探したところ, 取 手市より TAP 事務局一高須地区の旧農協事務棟が紹介された。 既に高須地区には環境系の NPO 法人や社会福祉法人が活動拠点 を持っており, TAP が入ることで新たな主体間及び公民館等の地

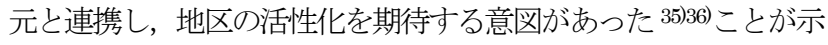
唆されている。

高須八ウスができるにあたり, 区長会, 高須公民館長, 高須公 民館運営委員会, 取手市, TAP 事務局同席のもと説明会が行われ た。説明会では, TAPの活動に関して特に出席者からはネガティ ブな反応は出なかった 29136)37)。元々，TAP は取手市で行われてき たプロジェクトであり, 旧藤代町エリアの高須では馴染みが薄く, 高須でどのような活動が行われるのかよくわからなかった 29) と いう意見が確認された。一方，旧来の高須地区は住民同士の結び つきが強く, 外部の者を容易に受け入れない雰井気があった 29)37) という。そのような地区において, よく分からない主体が入るこ とに反対意見等が出なかったということは，かつての地域の強い 結びつきが失われてきていたとも読み取れる。

\section{（2）高須ハウスの運営の特徵と課題}

高須八ウスの建物については，農協と市が協定を結んでおり， 農協から市が, 市から TAP 事務局が借用し使用している。建物 については外壁からの漏水や内部仕上げの劣化等, 老朽化が進ん でいるが，農協にとっては事業上は不要な資産であり劣化の改修 に投資する理由を持ち合わせておらず，一方の TAP としては高 須八ウスの大規模改修に投資する財源を確保することは困難であ る。取手市としても, 限られた予算の中での効率的な施設マネジ メントが重要とされている現在, 新たに高須八ウスに投資するこ とは難しいといら実態がある。そのため, 高須八ウスの運営にあ たり現在の建物を使い続け，高須における中長期的ビジョンを持 ってプロジェクトを計画・実施していき難いという課題がある 33)

旧農協を高須八ウスとして使用するにあたり, TAP 事務局及び アーティストが老朽化していた建物をリノベーションし，アトリ エやギャラリー，活動に必要な水回りの設備を整備した。リノベ ーション費用や運用に係る光熱水費については TAP から支出さ れている。高須八ウスの運営については取手市や文科省等による 補助金が活用されているが，それらは主にアート制作等に関寸る ものであるため, 活動に必要な場とはいえ建物の修繥費に充てる ことはできない。そこで, 高須八ウス内部のアート作品について は, 壁の漏水跡補修を兼ねた壁画や，階段の手摺を兼水た彫刻等 の制作に補助金を活用し，空間と一体化したアートでありながら 実質的な効果も発揮されるような運営上の工夫が確認された ${ }^{34)}$ 。

\section{（3）TAP の活動を契機とした高須地区内の多主体の関係構築}

高須公民館一帯で活動する主体間の関係を図一 3 に示す。TAP をはじめとする新たな主体と地域住民との関わりは主に，1. 高 須八ウスができる以前から地域住民によって行われてきたイベン トに新たな主体が参加することによる関わり，2，イベント以外 の日常時における関わり，3. TAP の特徵を生かしたアート関連 の活動を通した関わりの 3 つに整理することができる。

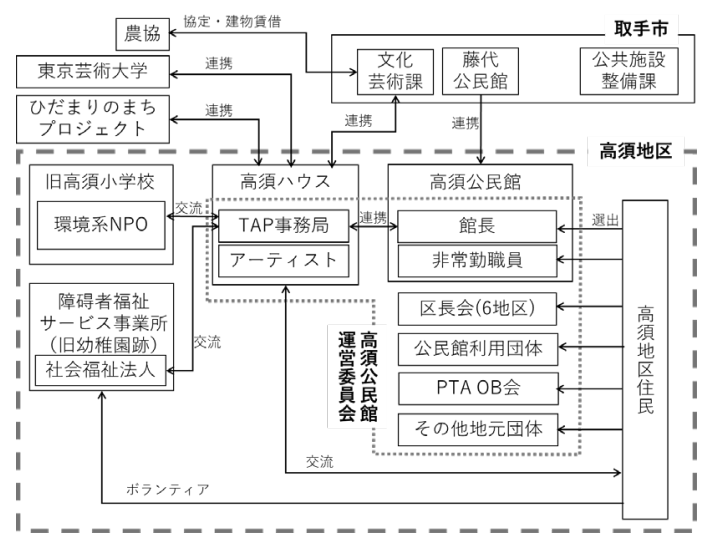

図－3＼cjkstart第IV期における関連主体の関係 
1）イベントを通した新たな主体と地域との関わり

盆踊りに代わり始まった高須フェスティバルにはTAP, 環境系 NPO, 社会福祉法人も協力している。2013 年に高須公民館の第 8 代館長が高須フェスティバルへの参加・出店を持ちかけたこと から始まり，TAPが間を繋ぐかたちで環境系 NPO や社会福祉法 人も参加することとなった。出店の内容については各団体の特徵 を生か寸ものとなっており, TAP は市内の中学校の美術部と連携 したフェイスペインティングや敷地内で栽培しているブルーベリ 一を使用したドリンクの販売，環境系 NPO については搾油した 油で揚げたポテト，社会福祉法人については事業所で製造したパ ンやお菓子の販売等である。TAP らが参加する以前の高須フェス ティバルについては，毎年殆じ同じ内容で実施されており形骸化 していた部分もあった 37$)$ というが，新たな主体が入ったことで, アートのワークショップ等これまで高須地区に無かった体験が得 られる点，近隣にありながら高須フェスティバルとは接点が無か った中学校の参加が始まった点, 形骸化していた部分に対して新 たな視点からの改善意見が得られる点について，地元住民からは 歓迎する意見が聞かれた ${ }^{37)}$ 。TAP が参加し始める以前, 社会福祉 法人の運営する障碍者福祉サービス事業所が高須にできた際にも 当時の公民館長よりフェスティバルへの参加依頼がなされ， 1 度 は参加が実現したものの翌年以降継続しなかったという。その後 TAP を通じ改めて参加を呼び掛けたところ, 社会福祉法人の運営 が安定し始めていたこともあり毎年の参加が実現している。

高須地区では古くから地域住民間の結びっきによってイベント や年中行事が䋭続されてきた。近年では廃止されたものも多いが, 盆踊りが形を変えて継続されている高須フェスティバルは地域に とっての大きなイベントであり，新たな主体が地域に入ると，ま ず高須フェスティバルへの参加を促すということからも地域のコ ミュニティ形成と維持において重要な場になっているといえる。

2）日常における新たな主体と地域との関わり

TAP が高須八ウスで活動開始してから 5 年が経過し, 現在では 日常的に地元住民や公民館等との関わりも生まれている。2017 年のアーティスト滞在プロジェクトをきっかけに地元小学生が日 常的に高須八ウスに遊びに来るようになり，アーティストとの交 流が現在も継続している36)こと，アーティストの持つ道具や技術 を生かして地区のゴミ集積カゴ作成や公民館の破損修繥が行われ

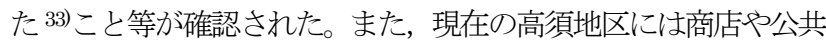
交通が無く, 2013 年からスーパーの移動販売が週 2 日間高須公 民館に来ており, 買い物も地域との交流の場となっているという。

半農半芸の一環として，高須八ウスの敷地内にある既存花壇で ブルーベリーの栽培，高須公民館一帯の向い側にある農地で綿花 や野菜の栽培が行われている。ブルーベリーについてはオリジナ ルのインクを作る，食材として遊びに来た小学生と実を摘む，高 須フェスティバルで実を使ったドリンクを提供する，更には高須 ハウスのパンフレットにブルーベリーのイラストが描かれる等, 高須ハウスでの TAP の活動全般に活かされている。綿花や野菜 の栽培については，農地を所有する住民から申し出があり 2015 年から共同耕作といら形で活動が行われている。高須八ウスで活 動するアーティスト達の様子が地域住民の目に触れる機会が増え, 野菜の栽培に関するアドバイスや苗の提供を受ける等の交流が生 まれている ${ }^{36)}$ 。地域の空間を活かし農という住民に馴染みの深い 接点を持ったことが, アートだけでは交流を持ちにくい住民との 間の関係構築に寄与していると考えられる。

更に，新たな主体の TAP・社会福祉法人・環境系 NPO との間 にも連携がみられる。社会福祉法人の活動ではパンやお菓子の製 作が行われていることから, 半農半芸プロジェクトの一つである 食堂でそのパンを仕入れて提供する, TAP のアーティストが環境 系 NPO の商品ラベルのデザインを行いラベル貼り作業を社会福
祉法人で行う等, 相互の特徵を生かした連携が模索されている 36) 3）アート関連活動を通した新たな主体と地域の関わり

高須八ウスでは活動内容の地元への発信として, 2016年よりか

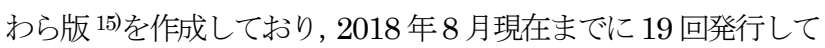
いる。月 1 回行われる高須地区の区長会会議入出席する際に印刷 したかわら版を持参することで, 各地区の回覧版と共に地区内一 配布している。内容としては滞在しているアーティストの紹介や イベント告知, アート制作に関する材料提供の呼びか的等であり, 内容によって異なる年齢・職業の住民が反応を示すという ${ }^{36)}$

アートのワークショップに参加した地元住民との交流をきっか けに，新たな活動も生まれた。高須地区や近隣市に住む主婦の活 動グループ「ひだまりのまちプロジェクト38)（以下，ひだまりと 記載)」と TAP が連携し，マルシェを 2016 年から毎年高須八ウ スを中心とした公民館一帯の屋内外で開催しており, 2016 年には 300 名以上, 2017 年には 500 名以上もの来場者を集めている。 連携における役割分担としては, 出店者選定についてはひだまり が担い, 一方の TAP はチラシ作成, 会場デザイン及びセッティ ングに加え, パートナーアーティストの中から現代舞踊のグルー プを選定しマルシェとアートのコラボレーションを実現させた。 マルシェの際, 高須公民館では出店者及び出演者の休憩所，子連 れの来場者用のオムツ交換スペース，マルシェで提供する食事の 調理等，施設の立地と特徵を生かした連携が行われた。ひだまり との連携はマルシェ以外にも発展しており，ひだまりの主催する ワークショップ会場として高須八ウスを提供する, 高須八ウスで のイベントへのひだまりのメンバーの参加等が継続している。ひ だまりはアートの専門ではないグループであるものの, TAP と価 值観を共有し相互の連携だけでなく地域との関わりを構築できて いる点において貴重な存在となっている 15)36)

\section{（4）新たな主体の活動の展開に伴う地域運営の変化}

従来，高須地区は住民同士の強固な関係から，外部の者を容易 には受け入れない地区であったというが，現在では住民が TAP をはじめ新たな主体に対して積極的に地域の重要なイベントへの 参加を求め, 新たな活動や体験を楽しむ様子が確認された 37 )。 た2018年度からは高須公民館運営委員会にTAP も参加している。 公民館運営委員会は，実質的には公民館にとどまらず高須地区の 運営を担っており，その一員として新たな主体が参画することは 今後の地域運営において大きな意義を持つ。社会福祉法人及び環 境系NPO と地元住民を繋ぐ役割をしている TAPがまず参加する ことで，今後更に他団体も地域運営に加わる契機となることが期 待されている。TAPが高須で活動を開始して 5 年が経過し, お客 様的存在としてイベントへの参加が求められていた状態から, 共 に地域を運営する仲間として受け入れられたことの表れであると 考えられる。更に 2018 年 8 月, 区長会会議へTAP・社会福祉法 人・環境系 NPO の 3 団体が招かれ, 今後の地域運営における連

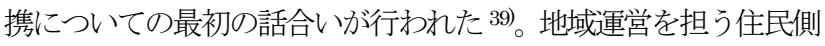
が新たな主体を受け入れ, 連携が深まっていく様子が確認できる。

TAPの活動ではかわら版やマルシェ等, 地域との関係構築を主 眼にしたものが見られるようになり, 社会福祉法人も高須地区の 地域住民との積極的な関わりが始まっている。施設の一部を地域 住民一開放し地域の居場所づくりに寄与するサロンの定期開催や， 学校の長期休㗇中の子供たちへの昼食提供等が行われている 40)。 ここでは, 新たな主体の活動内容や地域住民との関わり方に関寸 る位置づけの変化が表れているといえる。

\section{6. 公共的施設を拠点とした多主体の連携と地域運営}

多主体の活動の連携と地域運営の観点から，今後の都市近郊農 村が地域の特徵を活かして持続していくことに寄与する公共空間 マネジメントの在り方を考察する。 


\section{（1）地域の生業や歴史を踏まえた公共空間の機能設定}

高須地区では，明治期から小学校や村役場が置かれた敷地を拡 張・分割しながら一帯の公共空間が形成された。その空間は地域 の生業である「農」と, 幼稚園による就学前教育から現在の公民 館での生涯学習に至るまでの「教育」の接点として存在し続けて きたことに加え, 最近では TAP といら新たな主体によって半農 半芸といらプロジェクトがもたらされた。地元住民にとって「芸 (アート)」の部分は馴染みが無いものの,「農」については馴染 み深く, 経験や知識を有する住民も多いため, 地域にとっての新 しいことと馴染みのあることの双方があることで受け入れられ易 かったのではないかと推察できる。このことから, 多様な世代の 地元住民はもとより多様な主体が関与すること，地域の生業や歴 史との関係を繋ぐことが可能となるような機能を公共空間に付与 し，地域の拠点として設定することが重要であると考えられる。

\section{（2）民間敷地の公共空間化}

高須公民館一帯には複数の公共施設と民間の施設が隣接して立 地しているが，敷地境界で空間が区切られていないことから，各 施設の屋内外の空間の特徵及び一体的な公共空間としての拡がり を活かした年中行事やイベントが多主体の連携により行われてき た。一方で公共空間における活動主体の減少や活動に係る費用面 の問題から，活動の多様性や主体間の連携がそしくなった時期も あった。その後, TAP や社会福祉法人等の新たな主体によって公 共空間に再び地元の人々を引き込むきっかけになり得るブルーべ リーの栽培やアートの展示，手芸サロン等が行われていた。公共 空間における植栽や囲障の選定・配置, 空間の特徵を活かしたイ ベントの企画等が多様な活動を誘発し，多様な人々が公共空間に 集うきっかけとなっているといえる。加えて, TAP が高須八ウス に隣接する農地で地元住民と共同耕作を始めたことで，地域の目 に触れる機会が増え，次第に他の住民らと TAP の間に交流が生 まれたことが確認された。新たな主体に理解を持つ住民が活動の 場を提供したことを発端に，他の住民にも公的な活動に関与する 機会が広がった。また, TAP にとってはアートと地域を結びつけ る空間を得たことで，活動の公共性が向上したとも捉えられる。

所謂公共施設だけでなく民地も公共空間になり得ることを地域 住民が認識寸ることで，次の活動の展開にもつながることが期待 でき，持続的な地域運営にも結び付くものであると考えられる。

\section{（3）新たな主体を含めた地域と行政の役割分担}

高須公民館一帯の運営においては，公民館の代々の館長が地元 から選出されている点, 新たな主体を加えた地元住民で構成され る公民館運営委員会による運営が継続して行われている点に大き な特徴がある。また，公民館自体の稼働率は低い一方で，公民館 一帯の民間の施設・敷地でも公共的・地域貢献的な活動が展開さ れていた点も特徵的である。マネジメントの観点から公共施設の 効率化が重要視される現在において，最低限の費用やマンパワー での管理運営により公共サービスの質低下が䀣念される事例も多 い。それに対して高須公民館一帯では，公共空間で行われる活動 や施設の運営に携わるメンバー及び空間の供出を行政に頼らず, 住民主体で行われていた。公共空間の存在意義に関する認識が, 新たな主体も含めた地域全体で共有化されているといえる。

ここで行政が果たしていた重要な役割は，公共的な・地域貢献 につながる活動を行うことに意義を持つ複数の主体の当面の活動 の場として公共施設を提供し，新たに地域と結びつけたというこ とである。今後の公共施設のマネジメントを鑑みると，行政の所 有・管理する狭義の公共施設だけでなく民間の施設や敷地を含め た空間を，住民自らが公共空間として使い・維持していくことを 目指した地域と行政の役割分担が重要であるといえる。

\section{（4）今後の課題と展望}

今後は立地適正化や公共施設マネジメント推進の動きから, 中
心市街地への公共施設集約の動きが加速化する反面，このような 都市近郊における低未利用地及び施設の活用，官民多主体の連携 がこれまで以上に求められ，地域の特徵を活かした持続的な地域 運営に資する公共空間マネジメント手法の確立に向けて類似事例 分析の積み上げが求められる。

謝辞: 本研究を行うにあたり, 取手市公共施設課, 同文化芸術課, 取手市藤代公民館, 高須公民館, 取手アートプロジェクト事務局, 社会福祉法人ポニーの会, NPO 法人バイオライフの皆様にご協 力頂きました。深く感謝申し上げます。

\section{補注 · 文献}

1) 日本建築学会 (2015) : 公共施設の再編 計画の実践と手引き, 2

2) シビックプライド研究会 (2015) : シビックプライド 2 [国内編, 株宣伝会議

3）福岡孝則・遠藤秀平・柣橋修 (2017) : Livable City をつくる, (株)ルモ出版

4) 総務省 $(2016)$ : 暮らしを支える地域運営組織に関する調査研究事業報告書, 1

5）ハンナ・アレント (1994)：人間の条件，ちくま学芸文庫

6）出口敦・宋俊煥 (2015) : 公開空地等の公共空間ストック形成の潮流と変遷, 都市 計画, 64 (5), 22 - 29.

7）藤代市史通史編に記載の明治 43 年の地図, 1947 2008 年までの間の計 8 枚の空中 写真及ひ現在の地図を比較した

8) 藤代町総務部秘書広聴課（1995）: 合併 40 周年記念 95 藤代町町勢要覧，藤代町

9) 藤代町 (2004) : 藤代町合併 50 周年記念誌，藤代町

10）藤代町史民俗調査委員会（2005）：藤代町史・暮らし編，東日本印刷侏式会社

11）藤代町田園都市協会・高須農村集落センター委員会（1979）：高須農村集落センタ 一竣丁式パンフレット

12）藤代町役場総務課（1979）：広報ふじしろ第211 号

13）記念誌編集部（1979）：たか寸百年のあゆみ，高須小学校創立百周年記念事業実行 委員会

14）高須公民館，たか寸タイムス，1999２018年5月号

15）高須編集室（取手アートプロジェクト事務局内），高須かわらばん，2016年 10 月 〜2018年 8 月号

16）ヒアリングについては 2018 年 7 11月に計 10 回実施した。対象者は，取手市公 共施設整備課職員 2 名, 同文化芸術課職員 2 名, 第 9 代高須公民館長, 第 8 代高 須公民館長，高須公民館臨時職員，藤代公民館職員 2 名，取手アートプロジェクト 事務局 2 名, 高須八ウス滞在アーティスト 1 名, 高須地区住民 1 名, 社会福祉法 人職員 1 名, 環境系 NPO 法人職員 1 名, 計 15 名である。

17） 金潤煥・浅野平八・広田直行 (2003) : 地域施設の再編に係る公民館の構成機能と 多様性, 日本建築学会計画系論文集第 68 巻第 569 号, $63-70$

18）西野達也・神門香菜・平野吉信 (2010) : 中国地方における市町村合併に伴う公民 館の再編状況とまちづくり拠点化に関する考察 : 日本建築学会計画系論文集第 75 巻第 657 号, $2537-2545$

19）倉知徹 (2011) : 県立学校と地域まちづくり組織の協働による学校施設の管理運営 と効果 : 日本建築学会計画系論文集第 76 巻第 669 号, $2127-2133$

20) 金斗煥 (2012)：過疎地域における NPO 活動の展開と住民参加に着目した実践的 地域運営方法 : 日本建築学会計画系論文集第 77 巻第 675 号, 1043-1052

21）三浦詩乃・出口敦 (2014) : 旭川市平和通買物公園のマネジメントの変遷に関する 研究 : 日本建築学会計画系論文集第 79 巻第 696 号, 405-413

22）武田史郎 (2017) : キャンパスと公園がつくるまちのファブリック : ランドスケー プ研究 $81(2), 133-135$

23）藤代町 (2004)：藤代町合併 50 周年記念誌，藤代町, 19

24) 藤代町史民俗調査委員会 (2005) : 藤代町史・暮らし編, 419

25) 取手アートプロジェクトホームページ〈https://toride-ap.gr.jp/about〉

26）記念誌編集部（1979）：たか寸百年のあゆみ，16

27) 藤代町史民俗調査委員会 (2005) : 藤代町史・暮らし編, 385

28) 藤代町史民俗調査委員会 (2005) : 藤代町史・暮らし編，384

29) 2018 年 9 月 18 日高須公民館第 8 代・9 代館長ヒアリングによる

30) 藤代町史民俗調査委員会 (2005) : 藤代町史・暮らし編, 425

31) 2018 年 8 月 20 日高須公民館第 9 代館長・臨時職員ヒアリングによる

32）竣丁時の各種資料には「高須コミュニティ農村集落センター」と記載があるが, 䇋 工2 年後に改正された旧藤代町の例規集に含まれる設置管理条例には「高須公民 館」の記載がある。その間のどの時点で正式な施設名称が高須公公民館に変更され たのか、明らかでない(2018 年 9 月 3 日取手市公共施設整備課・藤代公民館職員, 4 日同文化芸術課ヒアリングによる)。

33) 2018 年 9 月 3 日取手市公共施設整備課・藤代公民館職員ヒアリングによる

34) 取手市 (2016), 取手市公共施設等総合管理計画

35) 2018 年 8 月 7 日取手市文化芸術課ヒアリングによる

36) 2018 年 8 月 20 日 TAP 事務局・滞在アーティストヒアリングによる

37) 2018 年 9 月 4 日高須地区住民ヒアリングによる

38） 2015 年設立の任意団体であり, 龍ケ崎市・取手市等を中心にイベントを企画・実 施している。メンバーの一人が高須地区在住であり TAP 主催のワークショップを きっかけ忛に交流が始まった（2018年 8 月 20 日 TAP 事務局ヒアリングによる）。

39) 2018 年 11 月 26 日環境系 NPO 法人ヒアリングによる

40) 2018 年 11 月 22 日社会福祉法人職員ヒアリングによる 